\title{
PEMIKIRAN IBNU QAYYIM AL-JAUZIYAH TERHADAP PARADIGMA PERUBAHAN HUKUM
}

\author{
Rizal Darwis \\ Fakultas Syariah IAIN Sultan Amai Gorontalo \\ rizaldarwis@iaingorontalo.ac.id
}

\begin{abstract}
This paper aims to explore the thought of Ibn Qayyim al-Jauziyah about the change of law. Ibn Qayyim al-Jauziyah in his legal thought gave the tremendous space for ijtihad in responding the change as an unavoidable reality. The paradigm of law change is inseparable from times, places, situations, intentions and customs factors. Ibn Qayyim al-Jauziyah's law change theory is "a renaissance" concept in Islamic legal thought. This implies that Islamic law is a dynamic law, responsive and adaptable to the demands of change. The implications of al-Jauziyah's law change theory to society are in order to achieve the benefit for society as the objective of the law itself.
\end{abstract}

Keywords: Islamic law, Ibnu Qayyim al-Jauziyah, legal thought

\begin{abstract}
Abstrak
Tulisan ini bertujuan untuk mengeksplorasi pemikiran Ibnu Qayyum al-Jauziyah tentang perubahan hukum. Ibnu Qayyim al-Jauziyah dalam pemikiran hukumnya memberikan ruang seluas-luasnya terhadap pintu ijtihad dalam merespon perubahan sebagai sebuah realitas yang tidak bisa dihindari. Paradigma perubahan hukum itu tidak terlepas dari faktor zaman, tempat, situasi, niat dan adat. Teori perubahan hukum Ibnu Qayyim al-Jauziyah merupakan konsep pembaharuan pemikiran hukum Islam. Hal ini berarti hukum Islam adalah hukum yang dinamis, responsif dan adaptabilitas terhadap tuntutan perubahan. Implikasi teori perubahan hukum al-Jauziyah
\end{abstract}


68| Rizal Darwis

pada masyarakat adalah dalam rangka tercapainya kemaslahatan masyarakat sebagaimana tujuan hukum itu sendiri.

Kata Kunci: Hukum Islam, Ibnu Qayyim al-Jauziyah, pemikiran hukum

\section{Pendahuluan}

Hukum Islam merupakan sistem hukum yang diyakini mempunyai kebenaran universal. Universalitas tersebut tampak pada daya adaptatifnya yang melampaui batas-batas wilayah dan zaman. Hukum Islam senantiasa aktual seiring perkembangan peradaban manusia dan perubahan zaman. Dalam kerangka ini, hukum Islam mesti diyakini sebagai tata nilai dan tata aturan yang diproyeksikan untuk menjadi solusi atas problematika hidup manusia dengan segala persoalan yang melingkupinya.

Hukum Islam yang secara dogmatis teologis bersumber dari wahyu Allah swt. semata-mata diperuntukkan bagi manusia agar dapat menjalani kehidupannya secara beradab. Artinya bahwa Allah swt. sama sekali tidak mempunyai kepentingan sedikit pun terhadap hukum Islam. Ketentuan-ketentuan hukum Islam ditetapkan Allah swt. demi kemaslahatan hidup manusia, sehingga beban hukum (taklif) hanya terdapat dan berlaku bagi manusia (mukallaf). Kewajiban, perintah, larangan, ketentuan halal, haram dan sebagaianya hanya berlaku bagi manusia semata. ${ }^{1}$

Kaitannya dengan tuntutan perubahan sosial dewasa ini, hukum Islam harus mampu memberikan jawaban yang memuaskan bagi kebutuhan manusia.Hukum Islam harus terlibat secara langsung dalam memecahkan persoalan manusia dalam ranah globalisasi. Artinya, konsepsi hukum Islam harus lebih dekat kepada manusia dan menjadikannya hukum Islam membumi pada diri manusia.

${ }^{1}$ Rahmatunnair, "Responsibilitas Hukum Islam di Tengah Perubahan Sosial,"Makalah, disampaikan pada kajian Rutin FKI Ulul Albab STAIN Watampone tanggal 16 Mei 2009. 
Kehidupan manusia di bumi senantiasa mengalami perubahan, sehingga hukum Islam harus selalu diinterpretasikan agar tetap menemukan konteksnya dalam kehidupan manusia yang senantiasa dinamis. Ketakutan dan ketidakmampuan menginterpretasikan hukum Islam sesuai dengan perubahan zaman dipandang sebagai ancaman bagi kelangsungan dan eksistensi hukum Islam di tengah arus perubahan dewasa ini.Bahkan ketidakberanian melakukan perubahan hukum merupakan pembunuhan karakter hukum Islam yang fleksibel dan dinamis.

Argumen teologis filosofis yang mendasari perlunya melakukan perubahan hukum Islam, di antaranya: Pertama, hukum Islam menganut teori perubahan demi terciptanya perbaikan dan kemajuan manusia dalam mewujudkan kemaslahatan. Doktrin perubahan ini tampak dalam pesan Alquran yang menyebutkan "Sesungguhnya Allah tidak akan mengubah nasib suatu kaum sebelum kaum itu sendiri mengubah dirinya" (QS Ar-Rad/13: 11). Kedua, epistemologi pemikiran hukum Islam tidak mempertentangkan antara ketentuan normatif dalam teks suci dengan realitas sosial masyarakat. Dalam hukum Islam, terdapat dialektika antara teks hukum dengan realitas sosial yang diformulasi dalam istilah ijtihad. Idealitas hukum Islam dan realitas sosial adalah dua variabel yang tidak terpisahkan dalam konsep ijtihad. ${ }^{2}$

Dalam konteks tersebut, perubahan hukum Islam berdasarkan pertimbangan perubahan sosial adalah sesuatu yang niscaya, bahkan keharusan. Dikatakan demikian karena merealisasi idealitas hukum Islam tidak boleh dilepaskan dari realitas sosial kehidupan manusia yang menjadi obyek dari idealitas hukum. Kenyataan kehidupan sosial manusia harus diajak berdialog untuk memproyeksikan sebuah perubahan formulasi hukum Islam, sehingga pada gilirannya terbangun suatu formulasi pemikiran hukum Islam yang diterima oleh

2 Rahmatunnair, Dialektika Hukum Islam: Antara Teks dan Realitas, Makalah, disampaikan pada Pelatihan Epistemologi PMII Cabang Bone pada tanggal 7 Maret 2009 di Kampus STAIN Watampone. 
realitas kemanusiaan yang sangat produktif menciptakan perubahan yang signifikan.

Durkheim sebagai dikutip Sukanto menyatakan hukum itu adalah refleksi dari solidaritas sosial masyarakat, baik itu bersifat mekanis maupun organis. Solidaritas mekanis ini pada masyarakat sederhana dan homogen di mana ikatan warganya didasarkan atas hubungan-hubungan pribadi serta tujuan yang sama. Sedangkan solidaritas organis pada masyarakat heterogen dengan pembagian kerja yang kompleks. ${ }^{3}$ Pitirin Sorokin menjelaskan pula bahwa perkembangan hukum dan gejala-gejala sosial sesuai dengan tahapan-tahapan yang dilalui dan berkembang di masyarakat. Nilai tersebut yaitu ideational (kebenaran absolut dari Tuhan), sensate (pengalaman), dan idealistic (wahyu dan pengalaman). Kesemuanya merespon perubahan-perubahan yang terjadi di masyarakat. ${ }^{4}$

Arnold M. Rose mengemukakan bahwa terjadinya perubahan-perubahan sosial di masyarakat dikarenakan adanya penemuan-penemuan di bidang teknologi, konflik antara kebudayaan dan gerakan sosial. Lebih lanjut dijelaskan William F. Ogbun bahwa penemuan di bidang teknologi adalah faktor utama terjadinya perubahan sosial dikarenakan mempunyai daya kembang yang kuat; adanya pembauran dua kebudayaan yang berbeda, dan timbulnya gerakan sosial dikarenakan adanya ketidakpuasan terhadap bidang kehidupan sosial, sehingga timbul keadaan tidak tenteram. ${ }^{5}$

Pandangan Durkheim dan Rose di atas menunjukkan bahwa segala perubahan yang terjadi di masyarakat akan mempengaruhi sistem sosial masyarakat tersebut, baik itu nilai, sikap dan pola perilakunya. Artinya suatu perubahan di bidang tertentu akan mempengaruhi bidang-bidang lainnya, termasuk

${ }^{3}$ Soerjono Soekanto, Sosiologi: Suatu Pengantar (Jakarta: RajaGrafindo, 2009), h. 155.

${ }^{4}$ Pitirim A. Sorokin, Contemporary Sociologial Teories (New York: Harper and Brothers, 1928), h.739.

${ }^{5}$ Soerjono Soekanto, Pokok-Pokok Sosiologi Hukum (Jakarta: Rajawali Pers, 2012), h. 110. 
dalam bidang hukum itu sendiri, di mana hukum lebih merupakan akibat dari faktor-faktor yang mempengaruhinya. Hukum di sini menjadi sebuah sistem yang terbuka untuk dijadikan terobosan terhadap kajian untuk bertoleransi dengan unsur-unsur lan yang berada di luarnya dengan memfleksibelkan perubahanperubahan sosial yang terjadi di masyarakat.

Di sisi lain, para ahli lain berpendapat bahwa perubahan sosial terjadi disebabkan adanya perubahan dalam unsur-unsur yang mempertahankan keseimbangan masyarakat, baik itu perubahan dalam unsur-unsur geografis, biologis, ekonomis, atau kebudayaan. Ada pula yang berpendapat bahwa perubahanperubahan sosial bersifat periodik dan non periodik. ${ }^{6}$

Nampak bahwa para sosiologis, filosof, sejarawan, dan ekonom telah berusaha membuat rumusan tentang prinsip dan hukum terhadap perubahan sosial, di mana mereka mengatakan terjadinya perubahan-perubahan sosial wajar timbul dari pergaulan hidup manusia. Ulama fikih dan ushul pun tidak ketinggalan mengemukakan pandangannya dalam memahami hukum, dan pada gilirannya melahirkan perbedaan teori perubahan hukum. Dalam implementasinya, hukum yang telah ditetapkan ulama fikih bisa berubah dengan merujuk pada hukum yang ditetapkan ulama ushul. Salah satu ulama fikih tersebut adalah Ibnu Qayyim al-Jauziyah merumuskan teori tentang perubahan hukum dan selanjutnya akan dieksplorasi dalam tulisan ini.

\section{Biografi Singkat Ibnu Qayyim}

Ibn Qayyim al-Jauziyah bernama lengkap Abu Abdullah Syamsuddin Muhammad bin Abu Bakar bin Ayyub bin Saad alDamasyqy al-Jauziyah. Beliau dilahirkan pada tahun $691 \mathrm{H} / 1292$ $\mathrm{M}$ dan wafat pada tahun $751 \mathrm{H} / 1350 \mathrm{M}^{7}$ Beliau adalah seorang

${ }^{6}$ Soerjono Soekanto, Sosiologi: Suatu Pengantar, h. 263.

${ }^{7}$ Mengenai tahun wafatnya terdapat perbedaan. Dalam kitab Dar alMa'arif al-Islamiyah disebutkan bahwa beliau meninggal pada tahun $1356 \mathrm{M}$. Sementara dalam kitab I'lam al-Muwaqi'in disebutkan tahun meninggalnya pada 
pemikir, ahli fikih yang bermazhab Hanbali, mengusai filsafat, hadis, sejarah, dan ilmu kalam.

Ibn Qayyim banyak menimbah ilmu dari beberapa ulama besar, seperti Ali Shihab al-Nablisi al-Qabir, Ibn Taimiyah dan kepada ulama-ulama lainnya. Adapun murid-muridnya seperti Ibnu Katsir, al-Hafidz Zainuddin Abu al-Fariz Abdurrahman, Syamsuddin Muhammad bin Abd Qahhar al-Nablisi, Ibn al-Hadi dan lain-lainnya. Dalam kesehariannya, Ibn Qayyim dikenal sebagai seorang wara', tekun beribadah dan berpendirian teguh. ${ }^{8}$

Dalam perjalanan hidupnya, Ibn Qayyim dan gurunya Ibn Taimiyah pernah dimasukkan dalam penjara disebabkan mengharamkan haji ke masjid Ibrahim.Beliau terkenal berpegang teguh dalam membela kemurnian Alquran dan hadis. Ibnu Qayyim juga menantang keras berbagai paham sufi yang bertentangan dengan Alquran dan hadis, seperti konsep wahdatul wujud, ittihad danhulul. Menurutnya, paham-paham tersebut lebih banyak menggunakan konsepsi akal, dan tidak jelas rujukan sumbernya. ${ }^{9}$ Pendapatnya dipandang cukup tegas karena tidak saja bersifat kritis terhadap berbagai aliran, namun juga sering terjadi perbedaan pendapat dengan ulama-ulama fikih mazhab Hanbali.

Ibnu Qayyim berada pada periode keenam dalam pembagian tasyri. Pada periode ini ditandai dengan meluasnya fanatisme dan taklid kepada imam yang empat.Di sini beliau sebagai sosok pemikir dan pembaharu yangberusaha mengajak kembali berpegang teguh kepada Alquran dan al-Sunnah sebagaimana yang dilakukan oleh para ulama salaf. Beliau juga mengajak dalam bidang fikih, ilmu kalam, dan tasawuf untuk meninggalkan perbedaan dan pertikaian aliran, mengajak kebebasan berpikir dan memahami jiwa syariah dan menjauhi taklid. Beliau menolak paham fanatik dan taklid dengan membuka

$1350 \mathrm{M}$.

8 Abdul Mun'im al-Hifny, Mausu'at al-Sufiyah (Cet I; Kairo: Dar arRasyad, 1992), h. 333

${ }^{9}$ Abdillah F. Hasan, Tokoh-tokoh Mashur Dunia Islam (Cet. I; Surabaya: Jawara, 2004), h. 227 
pintu ijtihad dan kebebasan berpikir. ${ }^{10}$

Dalam hal melahirkan karya-karya ilmiah berupa kitab, maka beliau adalah seorang penulis produktif. Misalnya mengenai tauhid, seperti Syifa al-Alil fi Masail al-Qadha wa alQadardan Ar-Ruh. Dalam masalah fikih dan ushul fikih, seperti I'lam al-Muwaqqi'in, Bayan ad-Dalil ala Istiqna al-Musabaqat 'an atTahlil. Dalam ilmu tasawuf, seperti Iddat as-Sabirin, dan Al-Fawaid. Dalam ilmu sejarah, seperti Akhbar an-Nisa, dan Zaad al-Ma'ad, serta masih banyak lagi karya-karya lainnya. ${ }^{11}$

\section{Pemikiran Ibnu Qayyim al-Jauziyah tentang Perubahan Hukum}

Menurut Ibnu Qayyim al-Jauziyah bahwa perubahan hukum terjadi karena perubahan fatwa. Sedangkan perubahan fatwa terjadi perubahan aspek-aspek yang mengitari hukum itu. Dalam kitabnya I'lam al-Muwaqqi'in, al-Jauziyah mengatakan:

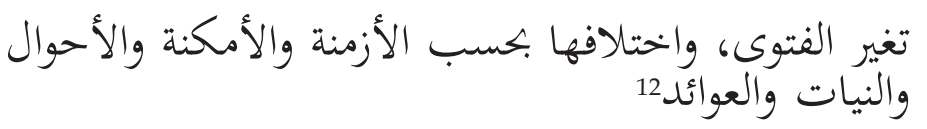

"Perubahan fatwa dan adanya perbedaan hukum tentangnya disebabkan faktor zaman, faktor tempat, faktor situasi, faktor niat, dan faktor adat."

Landasan teori pandangan al-Jauziyah tentang perubahan hukumpada prinsipnyamengacu hakikat syari'at Islam yang senantiasa berorientasi kemaslahatan manusia.Syari' at dihadirkan di bumi melalui Rasulullah bertujuan untuk mewujudkan keadilan hukum, kemaslahatan, dan kebajikan. Oleh karena itu, setiap ketentuan atau aturan hukum yang tidak memenuhi asas keadilan, dipandang bertentangan dengan syari'at Islam. ${ }^{13}$

10 Departemen Agama RI, Ensiklopedi Islam di Indonesia (Jakarta: Direktorat Jenderal Pembinaan Kelembagaan Agama Islam Depag RI, 1992 ), h. 403-405.

${ }^{11}$ Departemen Agama RI, Ensiklopedi Islam di Indonesia, h. 405.

${ }^{12}$ Ibnu Qayyim al-Jauziyah, I'lam al-Muwaqqi' in 'an Rab al-'Alamin, Juz III (Bairut: Dar al-Fikr, t.th), h. 14.

${ }^{13}$ Ibnu Qayyim al-Jauziyah, I'lam al-Muwaqqi'in 'an Rab al-'Alamin, h. 2. 
Dengan demikian, dapat dipahami bahwa perubahan hukum menurut al-Jauziyah terjadi karena perubahan kemaslahatan.

Kemaslahatan sebagai substansi syari'atmengalami perbedaan seiring dengan perbedaan zaman, tempat, situasi, niat dan adat. Itu artinya bahwa terjadinya perbedaan zaman, tempat, situasi, niat dan adat, menjadi legitimasi dan alasan bagi terjadinya perubahan hukum. Pandangan al-Jauziyah menunjukkan bahwa syari'at Islam bersifat fleksibel dan adaptif dalam merespon setiap perubahan dan perkembangan. Sejatinya, al-Jauziyah berpendapat bahwa hukum Islam dapat ditafsir dan diterjemahkan sesuai konteks sosial umat.

Eksplorasi lebih jauh tentang faktor-faktor perubah dalam hukum Islam menurut al-Jauziyah, sebagai berikut:

\section{Faktor Zaman}

Ketika Nabi Muhammad saw. berada di Mekkah, kemungkaran tidak langsung diubah karena pertimbangan zaman. Akan tetapi, setelah fath al-Makkah dan umat Islam meraih kemenangan, maka segala kemungkaran dapat diubah. ${ }^{14}$ Mencegah kemungkaran dalam hukum Islam adalah kewajiban bagi umat Islam, akan tetapi Mekkah di zaman itu belum memungkinkan dilakukan perubahan karena belum berada dalam situasi aman. Ketika Islam datang, masyarakat Mekkah berada dalam zaman kebodohan (jahiliyah), kemungkaran, dan berbagai kejahatan lainnya merajalela di tengah-tengah masyarakat. Dalam keadaan demikian, hukum Islam tidak dapat dipaksakan untuk diterapkan, tetapi melalui berbagai proses yang cukup panjang. ${ }^{15}$

Kaitannya dengan perubahan hukum, al-Jauziyah menunjukkan pada kasus pelarangan khamar yang dilakukan secara bertahap dengan proses yang panjang. Dalam hal ini, pelarangan terhadap khamar dimulai dengan menyatakan bahwa khamar itu merupakan kebiasaan orang-orang kafir (QS al-Nahl/16: 67). Dilanjutkan dengan menyatakan bahwa khamar

${ }^{14}$ Ibnu Qayyim al-Jauziyah, I'lam al-Muwaqqi' in 'an Rab al-'Alamin, h. 16.

${ }^{15}$ Ibnu Qayyim al-Jauziyah, I'lam al-Muwaqqi'in 'an Rab al-'Alamin, h. 16. 
itu terdapat manfaat dan mudharat, namun mudharatnya lebih besar daripada unsur manfaatnya (QS al-Baqarah/2: 291). Tahap berikutnya adalah pelarangan mengerjakan shalat dalam keadaan mabuk (QS al-Nisa/4: 43). Tahap terakhir adalah penegasan bahwa meminum khamar dan perbuatan-perbuatan tercela lainnya harus dijauhi (QS al-Maidah/5: 90).

\section{Faktor Tempat}

Al-Jauziyah menjelaskan bahwa Nabi Muhammad saw. melarang memotong tangan musuh dalam medan perang. Larangan ini diberlakukan oleh karena peperangan tersebut terjadi di wilayah musuh. ${ }^{16} \mathrm{Hal}$ ini berarti bahwa segala ketentuan hukum yang ditetapkan oleh syari'at pada suatu wilayah, tidak dapat dipaksakan pemberlakuannya di wilayah lain. Dengan demikian, perbedaan tempat dapat berimplikasi pada terjadinya perbedaan dan perubahan hukum.

Pengaruh faktor tempat bagi terjadinya perubahan hukum, juga tampak dalam penjelasan al-Jauziyah tentang kewajiban zakat fitrah berdasarkan makanan pokok dari penduduk suatu tempat. Nabi saw. menetapkan zakat fitrah berupa satu gantang kurma atau satu gantang gandum atau satu gantang anggur kering atau satu gantang keju bagi penduduk kota Madinah. Hal tersebut ditetapkan oleh Nabi Muhammad saw. berdasarkan bahwa jenis makanan yang telah disebutkan merupakan menu utama bagi penduduk Madinah. Adapun penduduk kota lainnya yang makanan pokoknya selain yang telah disebutkan, maka kewajiban bagi penduduk yang ada di kota tersebut untuk mengeluarkan zakatnya berdasarkan makanan pokok yang mereka konsumsi. Sebagaimana jika suatu daerah makanan pokok tersebut berupa jagung atau beras atau buah tin atau lainnya berupa biji-bijian, maka kewajiban bagi penduduknya untuk mengeluarkan zakatnya dari jenis makanan utamanya tersebut. Begitu juga halnya jika makanan utama tersebut berupa susu atau daging atau ikan, maka zakat fitrah yang wajib dikeluarkan oleh

${ }^{16}$ Ibnu Qayyim al-Jauziyah, I'lam al-Muwaqqi'in 'an Rab al-'Alamin,h. 17. 
penduduk daerah tersebut sesuai dengan makanan utamanya tersebut. ${ }^{17}$

Berdasarkan hal tersebut, maka menurut Ibnu Qayyim dibolehkan pula mengeluarkan zakat fitrah berupa makanan pokok apa saja sesuai dengan apa yang berlaku pada masyarakat setempat. Makanan pokok masyarakat Mekkah seperti gandum ketika itu, berbeda dengan makanan pokok bangsa Indonesia, yakni beras.

\section{Faktor Situasi}

Ibnu Qayyim mengkisahkan bahwa 'Umar bin al-Khattāb tidak mem-berlakukan hukum potong tangan bagi pencuri dalam musim paceklik. ${ }^{18}$ Sejalan dengan apa yang dikisahkan Ibnu Qayyim ini, Abbas Mahmud Akkad men-jelaskan lebih lanjut bahwa tindakan Umar yang tidak menjatuhkan hukuman kepada pelaku pencuriaan tersebut pada dasarnya tidak meninggalkan nash karena pelaku pencurian tersebut melakukannya secara terpaksa sebagai bagian dari tuntutan kelangsungan hidup dan keselamatan dari bencana kelaparan. Dengan demikian, pelaku pencurian tersebut dianggap sebagai orang yang tidak berdosa dengan perbuatannya tersebut. ${ }^{19}$

Perilaku mencuri oleh seorang pencuri yang karena kelaparan yang tidak tertahankan menyebabkannya melakukan tindakan terlarang oleh agama. Namun, dalam situasi yang mengharuskannya melakukan hal tersebut, tindakan yang tidak terpuji yang terpaksa dilakukaknnya merupakan prilaku yang dapat di tolerir oleh syariat Islam, karena prilaku tersebut dilakukannya dalam rangka menjaga jiwa yang merupakan salah satu unsur dari maqasid as-syar'i. Begitu pula dalam kaidah ushul "darurat membolehkan melakukan yang terlarang" yang dibuat oleh para ulama sebagai salah satu pertimbangan dalam menetapkan

${ }^{17}$ Ibnu Qayyim al-Jauziyah, I'lam al-Muwaqqi'in 'an Rab al-'Alamin,h. 9-10.

${ }^{18}$ Ibnu Qayyim al-Jauziyah, I'lam al-Muwaqqi'in 'an Rab al-'Alamin,h. 22.

${ }^{19}$ Abbas Mahmud Akkad, At-Tafkir Faridah Islamiyah (Kairo: Nahdhah Masri. t.th.), h. 100. 
hukum. Tentu, kaidah ini ditetapkan bukan dengan tujuan sebagai hiasan belaka, tetapi untuk digunakan sebagaimana mestinya. Dengan demikian tindakan Umar tersebut merupakan langkah yang tepat dalam penegakan hukum Islam.

\section{Faktor Niat}

Niat adalah "20 " قصد فعل مقترنا بفعله (menyengajakan untuk berbuat sesuatu disertai/berbarengan dengan perbuatannya). Kaitannya teori perubahan hukum dengan masalah niat, Ibnu Qayyim mengangkat kasus yang berkisar pada peristiwa dimana seorang suami mengatakan kepada istrinya "jika aku mengizinkanmu keluar menuju kamar mandi, maka jatuhlah talakmu." Oleh karena sesuatu dan lain hal, istrinya membutuhkan kamar mandi tersebut, maka berkatalah suaminya "keluarlah". ${ }^{21}$ Oleh sebagian masyarakat menganggap bahwa jatuhlah talak bagi sang istri hanya dengan kata "keluarlah". Sang suami kemudian mempertanyakan hal tersebut kepada seorang mufti. Jawaban sang mufti menegaskan bahwa talak telah jatuh kepada sang istri dengan perkataan "keluarlah" dari sang suami. ${ }^{22}$

Keputusan mufti tersebut, oleh Ibnu Qayyim dianggap sebagai suatu kebodohan karena kata "keluarlah" bukan dimaksudkan oleh sang suami tersebut sebagai izin. Tindakan mufti yang menceraikan suami dari istrinya tersebut adalah hal yang tidak diizinkan oleh Allah swt. dan Rasul-Nya. Begitu pula tidak diperbolehkan oleh para imam. ${ }^{23}$ Kasus yang dihadapi oleh Ibnu Qayyim ini, merupakan gambaran hukum bahwa ketetapan hukum tidak boleh mengindahkan niat dari pelaku hukum. Hal tersebut menunjukkan bahwa posisi niat dalam sistim hukum Islam menempati kedudukan penting yang mampu merubah suatu hukum yang telah ditetapkan.

${ }^{20}$ Muhammad Ismāil al-Kahlāni, Subul al-Salām min Adillat al-Ahkām (Bairut: Dar al-Fikr, 1979), h. 26.

${ }^{21}$ Ibnu Qayyim al-Jauziyah, I'lam al-Muwaqqi'in 'an Rab al-'Alamin,h. 44.

${ }^{22}$ Ibnu Qayyim al-Jauziyah, I'lam al-Muwaqqi' in 'an Rab al-'Alamin,h. 44.

${ }^{23}$ Ibnu Qayyim al-Jauziyah, I'lam al-Muwaqqi'in 'an Rab al-'Alamin, h. 44. 


\section{Faktor Adat}

Bagi Ibnu Qayyim, faktor adat sama halnya dengan 'urf yang termasuk salah satu faktor dapat merubah hukum. Dicontohkan dengan orang yang bersumpah untuk tidak mengendarai "dabbah". Dimana di daerah tersebut lafadz "dabbah" sesuai dengan "urf (adat) yang berlaku diartikan dengan keledai. Olehnya itu, sumpahnya hanya berlaku untuk tidak mengendarai hewan yang bernama keledai. Adapun jika orang tersebut mengendarai kuda atau onta, maka tidak ada konsekuensi hukum baginya. ${ }^{24}$ Begitu pula sebaliknya, jika yang dimaksud "dabbah" sesuai dengan 'urf (adat) pada daerah lainnya adalah kuda, maka sumpahnya tersebut hanya berlaku untuk hewan kendaraan yang bernama kuda. Hal ini menunjukkan bahwa perubahan hukum selalu mempertimbangkan 'urf (adat) suatu daerah.

Lebih lanjut menurut Ibnu Qayyim, jika seseorang mendatangimu dari daerah yang berlainan denganmu dan meminta keputusan hukum, maka tanyakanlah tentang 'urf (adat) yang berlaku di daerahnya dan berilah keputusan hukum berdasarkan 'urf (adat) yang berlaku di daerahnya bukan berdasarkan 'urf (adat) yang berlaku di daerahmu. ${ }^{25}$ Demikian juga halnya seorang mufti tidak dibolehkan mengeluarkan fatwa berdasarkan 'urf (adat) yang terjadi pada zaman yang telah berlalu. ${ }^{26}$ Dari uraian teori perubahan hukum yang terkait dengan adat tersebut, maka seorang penegak hukum hendaklah selalu mempertimbangkan faktor-faktor yang mempengaruhi penetapan suatu hukum. Ini juga berarti bahwa seorang mufti, pembuat dan penegak hukum harus berwawasan luas dan mengetahui aspek-aspek yang berpengaruh dalam penetapan hukum.

${ }^{24}$ Ibnu Qayyim al-Jauziyah, I'lam al-Muwaqqi' in 'an Rab al-'Alamin, h. 43.

${ }^{25}$ Ibnu Qayyim al-Jauziyah, I'lam al-Muwaqqi' in 'an Rab al-'Alamin,h. 67. Bandingkan Muhammad Said al-'Asymawy, Jauhar al-Islam (Cet III; Kairo: Sina, 1993), h. 29.

${ }^{26}$ Nadiyah Syarif al-Umry, Ijtihad fi al-Islam, Ushuluhu, Ahkamuhu, Afatuhu (Cet.I; Beirut: Muasasah ar-Risalah, 2001 ), h. 246. 


\section{Teori Perubahan Hukum Ibnu Qayyim dan Implikasinya Pada Masyarakat}

Adanya perubahan hukum sebagaimana yang dikemukakan Ibnu Qayyim, sesungguhnya berdasar pada realitas kehidupan masyarakat yang selalu berubah-ubah. Setiap masa dari generasi ke generasi tidak sama dengan masa yang dihadapi oleh generasi sebelum dan sesudahnya, sehingga perubahan hukum tidak dapat terhindarkan.

Di sisi lain, adanya perubahan hukum tersebut sesungguhnya sejalan dengan misi ajaran Islam yang senantiasa selalu relevan dengan situasi dan kondisi masyarakat, atau dalam istilah lain al-Islām shālih li kulli zaman wa makān. Masalah-masalah yang dimaksudkan tersebut untuk saat ini bisa saja terjadi dalam bidang ekonomi, seperti bunga bank dan asuransi. Di bidang kemasyarakatan seperti gerakan emansipasi wanita yang sedikit banyaknya berdampak pada kehidupan rumah tangga. Di bidang politik seperti kebebasan pers dan kebebasan membentuk partai, serta beroposisi terhadap pemerintah.

Esensi perubahan hukum yang disebutkan, pada dasarnya merupakan bahagian kecil dari sekian banyak permasalahan yang konsensus hukumnya bisa saja berbeda pada zaman, tempat, kondisi yang berlainan. Untuk itu, diperlukan suatu usaha yang keras dalam rangka menyelaraskan realitas kehidupan dengan hukum Islam yang bersumber dan berlandaskan nash Alquran dan Sunnah.

Disadari bahwa banyak di antara masalah-masalah yang timbul pada masa sekarang ini belum didapati solusi hukumnya pada khasanah fikih klasik. Begitu juga, ada masalah yang oleh ulama-ulama terdahulu telah menetapkan konsensus hukumnya sehingga dianggap final, namun relitasnya berkata lain sejalan dengan perkembangan zaman, tempat dan situasi. Oleh karena itu, pintu ijtihad harus senantiasa dibuka dalam rangka merealisasikan syariat Islam sebagai syariat yang sesuai untuk tiap zaman dan tempat. ${ }^{27}$

27 Definisi Ijtihad menurut ushuliyyin adalah pengerahan segala 
Kemajuan sains dan teknologi yang dihadapi masyarakat dewasa ini merupakan indikasi suatu kemajuan yang pesat bagi dunia. Oleh karena itu, umat Islam dewasa dihadapkan pada bermacam-macam tantangan global dan permasalahan baru yang belum pernah dibahas oleh ulama terdahulu.Sebagai implikasinya, maka permasalahan baru yang dihadapi harus dijawab melalui lembaga Ijtihad. Ijtihad harus digalakkan sebagai sarana pengkajian hukum Islam.

Dengan melihat kenyataan tersebut, maka ijtihad merupakan suatu keharusan yang mesti dilakukan sekaligus merupakan hal darurat yang tidak bisa dihindari. Suatu keharusan karena dilandasi oleh nash seperti jawaban yang diutarakan oleh Muaz bin Jabal ketika ditanya oleh Rasulullah saw. tentang tindakan yang harus dilakukannya sebagai hakim di Yaman. Begitu pula ijtihad merupakan hal yang darurat berdasarkan kenyataan dan realita yang terjadi pada zaman sekarang ini. Dengan adanya ijtihad, maka perubahan hukum bisa saja terjadi di tengah-tengah masyarakat.

Tentunyaperubahan-perubahanyang terjadidimasyarakat bisa disebabkan oleh faktor dari dalam (intern) masyarakat itu sendiri dan faktor dari luar (ekstern) masyarakat. Faktor dari dalam (intern) bisa berupa berkurang dan bertambahnya penduduk, adanya penemuan baru, revolusi manusia, munculnya pertentangan dan lain sebagainya. Sedangkan faktor dari luar (ekstern) bisa berupa lingkungan alam, pengaruh kebudayaan masyarakat lain, terjadinya peperangan dalam masyarakat dan lain sebagainya.

Sarjono Soekanto mengemukakan bahwa Arnold M. Rose membagi 3 bentuk teori dalam perubahan hukum, yaitu:

\footnotetext{
kemampuan yang dilakukan oleh seorang mujtahid untuk mengetahui hukumhukum syariah dengan jalan istinbath. Lihat Abdul Karim Zaedan, Al-Wajiz fi Ushul al-Figh (Cet II; Bairūt : Muassasah al- Risālah, 1987), h. 401. Definisi ijtihad tidak terlepas dari perbedaan para ahli fikih untuk melihat perbedaan tersebut, maka rujuk pada: Nadiyah Syarif al-'Umry, Ijtihad fi al-Islam, Ushuluhu, Ahkamuhu, Afatuhu,h. 19-28. Lihat pula Muhammad Faraj Salim, Al-Wajiz fi Ushul al-Figh (Cet II : Kairo : al-Iman, 1965), h. 291.
} 
(1) adanya perubahan hukum dalam masyarakat disebabkan adanya penemuan-penemuan di bidang teknologi; (2) adanya konflik antara kebudayaan, dan (3) munculnya gerakan sosial. Lebih lanjut dijelaskan oleh William F. Ogburn bahwa penemuan-penemuan di bidang teknologi adalah faktor utama yang menyebabkan terjadinya perubahan-perubahan sosial. Penemuan baru mempunyai daya berkembang yang kuat dan pesat; menyangkut konflik kebudayaan dikarenakan adanya dua budaya yang saling bersinggungan dan bertemu dalam sebuah masyarakat yang menyebabkan terjadinya perubahan sosial dalam masyarakat; sedangkan adanya gerakan sosial dikarenakan adanya ketidakpuasan sekelompok orang atau masyarakat terhadap bidang-bidang kehidupan tertentu, sehingga melahirkan gerakan yang menyebabkan ketidakamanan dan ketenteraman dalam masyarakat. Gerakan inilah yang menyebabkan terjadinya perubahan-perubahan sosial dalam masyarakat. ${ }^{28}$

Namun adanya perubahan-perubahan sosial yang juga menyebabkan perubahan hukum tidak selamanya bersamaan berlangsung. Pada keadaan tertentu, perkembangan hukum mungkin tertinggal oleh perkembangan kebudayaan suatu masyarakat, ataukah bisa sebaliknya. Kejadian ini menggambarkan ketidakseimbangan pada masyarakat yang nantinya mengakibatkan kepincangan-kepincangan.Hukum pada hakekatnya disusun, disahkan dan diterapkan oleh bahagian kecil masyarakat yang memiliki kekuasaan dan kewenangan, yang bisa berimbas pada sebuah kepentingan politik.Oleh sebab itu, kaidah hukum dan kaidah perubahan sosial adalah dua komponen yang tidak bisa dihindarkan dalam sebuah tatanan masyarakat.

Friedman Lawrence sebagaimana dikutip Taneko pernah menyebutkan bahwa fungsi hukum ${ }^{29}$ dalam kehidupan bermasyarakat antara lain:

28 Soerjono Soekanto, Sosiologi: Suatu Pengantar, h. 110.

29 Soleman B. Toneko, Struktur dan Proses Sosial (Cet. II; Jakarta: RajaGrafindo Persada, 1993), h. 37. 


\section{Hukum sebagai alat pengawasan/pengendalian sosial (social control)}

Hukum sebagai alat pengawasan atau alat pengendalian sosial berperan memaksa masyarakat agar berperilaku sesuai dengan aturan hukum yang berlaku. Di sini sebagai pengendalian sosial, maka hukum dapat bersifat preventif (pencegahan terhadap perilaku yang menyimpang), dan bersifat represif (mengembalikan keserasian yang terganggu).

\section{Hukum sebagai alat penyelesaian sengketa (dispute settlement)}

Manusia sebagai makhluk sosial yang menjalani kehidupan bersama-sama tidak bisa menghindari terjadinya gesekan dan benturan yang mengakibatkan percekcokan dan pertikaian. Di sinilah fungsi hukum berperan sebagai alat penyelesaian sengketa. Penyelesaian sengketa dalam masyarakat dapat dilakukan baik secara sendiri melalui bantuan orang lain di sekitarnya (musyawarah mufakat), maupun melalui lembaga hukum (peradilan).

3. Hukum sebagai alat rekayasa sosial (social engginering, redistributive, innovative)

Kehidupan masyarakat senantiasa berkembang dan mengalami perubahan. Perubahan-perubahan ini bisa dikarenakan faktor kemajuan ilmu pengetahuan dan teknologi ataukah faktor budaya dalam masyarakat. Kaitannya dengan hukum adalah menjadi alat untuk mengubah masyarakat ke suatu tujuan yang diinginkan bersama, di mana bisa diarahkan untuk mengubah pola-pola tertentu dalam suatu masyarakat. Dalam arti bisa mengokohkan suatu kebiasaan untuk lebih diyakini dan ditaati, ataukah menghilangkan suatu kebiasaan yang tidak sesuai lagi dengan kondisi masyarakat, ataukah membentuk suatu kondisi baru yang lebih sesuai dengan kondisi masyarakat tertentu.

Pada intinya ketiga bentuk fungsi hukum di atas adalah berperan untuk memberikan petunjuk kepada masyarakat 
untuk bagaimana harus bertingkah laku, dengan melihat mana sesuatu yang dibolehkan oleh hukum dan mana sesuatu yang tidak dibolehkan oleh hukum. Keberadaan hukum di sini dikarenakan sifat dan watak hukum adalah mengatur tingkah laku manusia, baik dengan cara memerintah maupun cara melarang.

Pandangan Ibnu Qayyim nampak sejalan dengan pandangan Durkheim, Rose dan Lawrence bahwa adanya perubahan hukum dikarenakan perubahan sosial yang terjadi di masyarakat, baik itu sebab dari dalam masyarakat itu sendiri, maupun dari luar masyarakat. Perubahan sosial dan perubahan hukum bisa berlangsung bersama-sama dan bisa tidak selalu berlangsung bersama. Dengan kata lain, dalam keadaan tertentu perkembangan hukum mungkin tertinggal oleh perkembangan unsur lainnya. Hal ini berimbas antara kaidah hukum dan kaidah sosial tidak bisa terhindarkan dalam sebuah masyarakat.

Faktor amkinah (tempat), al-azminah (zaman), al-ahwal (keadaan), al-niat (niat/kemauan), dan al-awaid (adat) sebagai sesuatu yang dapat mempengaruhi dan mengubah paradigma hukum, sehingga hukum itu bisa tetap dinamis, responsif dan adaptabilitas yang tinggi terhadap tuntutan perubahanperubahan sosial yang terjadi di masyarakat.

Di sini hukum adalah sebuah kesatuan norma yang mengatur obyek hukum (masyarakat), dimana masyarakat harus selalu terbuka terhadap suatu perkembangan. Pada posisi ini, hukum tidak boleh stagnan dan statis sehingga akan menimbulkan kehidupan masyarakat menjadi konstan (tetap). Hukum diharapkan akan selalu mengikuti perkembangan yang terjadi di dalam masyarakat. Tentunya konteks perubahan hukum dan perubahan sosial yang diciptakan dalam proses maupun hasil merupakan penggabungan identitas dan regularities (human agency) dengan proses perubahan sosial ke dalam analisis hukum terkait substansi hukum, struktur hukum dan budaya hukum itu sendiri, sehingga hukum di sini bisa menjadi alat pengawasan sosial, perekayasa sosial, dan alat penyelesaian sengketa sebagaimana pandangan Lawrence tentang fungsi hukum itu sendiri. 
Kaitannya dengan hukum Islam itu sendiri tidak terlepas dari posisi ijtihad sebagai dalil hukum yang mengawal keuniversalitas Islam sebagai ajaran agama yang shālih li kulli zaman wa makān. Alquran dan hadis Nabi saw sebagai sumbersumber hukum normatif tekstual sangatlah terbatas jumlahnya, sementara kasus-kasus baru yang terjadi di masyarakat terkait bidang hukum tidak terbatas jumlahnya. Di sinilah peran agama sebagai pengawal perubahan sosial untuk kemaslahatan umat Islam itu sendiri.

Keberadaan ulama sebagai pewaris para Nabi sangat berperan dalam menggali dan menetapkan sebuah status hukum dalam mencermati perubahan-perubahan sosial yang terjadi di masyarakat. Ibnu Qayyim adalah salah satu ulama fikih yang dengan teori perubahan hukumnya telah merumuskan pendekatan dan metodologi hukum sesuai dengan konteks yang melingkupinya dalam merespon perubahan-perubahan sosial di masyararakat dengan menjadikan al-amkinah (tempat), al-azminah (zaman), al-ahwal (keadaan), al-niat (niat/kemauan), dan al-awaid (adat) sebagai faktor-faktor pengubah hukum dalam masyarakat.

\section{Kesimpulan}

Ibnu Qayyim adalah pakar hukum Islam yang pemikirannya sangat kritis, pendapatnya dapat diterima dan diterapkan di era kontemporer. Pemikiran dan pendapatnya yang menonjol adalah teorinya tentang perubahan hukum. Menurutnya ada lima faktor yang memungkinkan terjadinya perubahan hukum, yakni al-amkinah (tempat), al-azminah (zaman), al-ahwal (keadaan), al-niat (niat/kemauan), dan al-awaid (adat). Kelima faktor ini, kelihatannya dapat ditujukan dalam upaya mensosialisasikan penegakan hukum di Indonesia.

Merujuk pada teori perubahan hukum yang dirumuskan Ibnu Qayyim, maka dirasakan implikasinya di tengah-tengah masyarakatera kontemporer, yakni perlunya usaha yang sungguhsungguh melakukan ijtihad. Dengan usaha ijtihad, maka hukum Islam menjadi fleksibel dan sejalan dengan misi ajarannya sebagai 
Pemikiran Ibnu Qayyim Al-Jauziyah terhadap Paradigma.... I85

rahmatan lil 'alamin, sehingga implikasi positifnya di tengahtengah masyarakat benar-benar dapat tersosialisasi dengan baik, dan agar hukum Islam dapat membawa rahmat kepada seluruh alam.

\section{Daftar Pustaka}

Akkad, Abbas Mahmud. Al-Tafkir Faridah Islamiyah. Kairo: Nahdhah Masri. t.th.

al-'Asymawy, Muhammad Said. Jauhar al-Islam. Cet III; Kairo: Sina, 1993.

Departemen Agama RI, Al-Qur'an dan Terjemahnya. Jakarta: Proyek Pengadaan Kitab Suci al-Qur'an, 1992.

. Ensiklopedi Islam di Indonesia. Jakarta: Direktorat Jenderal

Pem-binaan Kelembagaan Agama Islam Depag RI, 1992.

Hasan, Abdillah F. Tokoh-tokoh Mashur Dunia Islam. Cet. I; Surabaya: Jawara, 2004.

Al-Hifny, Abdul Mun'im. Mausu'at al-Sufiyah. Cet I; Kairo: Dar arRasyad, 1992.

Ibnu Qayyim al-Jauziyah, I'lam al-Muwaqqi'in 'an Rab al-'Alamin, juz III. Bairūt: Dar al-Fikr, t.th.

Al-Kahlani, Muhammad Ismāil. Subul al-Salam min Adillat alAhkam. Bairut: Dar al-Fikr, 1979.

Rahmatunnair. "Responsibilitas Hukum Islam di Tengah Perubahan Sosial." Makalah, disampaikan pada Kajian Rutin FKI Ulul Albab STAIN Watampone, tanggal 16 Mei 2009.

. "Dialektika Hukum Islam: Antara Teks dan Realitas." Makalah disampaikan pada Pelatihan Epistemologi PMII Cabang Bone pada tanggal 7 Maret 2009 di Kampus STAIN Watampone.

Salim, Muhammad Faraj. Al-Wajiz fi Ushul al-Figh. Cet. II; Kairo: al-Iman, 1965.

Soekanto, Soerjono. Sosiologi: Suatu Pengantar. Jakarta: Raja Grafindo Persada, 2009. 
86| Rizal Darwis

. Pokok-Pokok Sosiologi Hukum. Jakarta: Rajawali Press, 2012.

Sorokin, Pitirim A. Contemporary Sociologial Teories. New York: Harper and Brother, 1928.

Toneko, Soleman B. Struktur dan Proses Sosial. Cet. II; Jakarta: RajaGrafindo Persada, 1993.

'Umry, Nadiyah Syarif. Ijtihad fi al-Islam, Ushuluhu, Ahkamuhu, Afatuhu.Cet.I; Beirut: Muasasah ar-Risalah, 2001.

Zaedan, Abdul Karim. Al-Wajiz fi Ushul al-Fiqh Cet. II; Bairut: Muassasah al-Risalah, 1987.

Zuhrah, Abu. Ushul al-Fiqh. Mesir: Dar al-Fikr al-Arabiy, t.th. 